УДК 340.12

\title{
Integrative Methodology of Law Interpretation
}

\author{
Vladimir M. Syrykh* \\ Russian Academy of Justice \\ 14 Zubovskaya Str., Moscow, 119121, Russia
}

Received 11.02.2015, received in revised form 12.04.2015, accepted 29.04.2015

The article examines the materialistic type of law interpretation, integrating different approaches for the understanding of law. The conclusion is made on the special nature of the method of integrative law interpretation, the principles of its application in the process of law studying and on the staged implementation of the objective law.

Keywords: law interpretation, materialist theory of law, positive law, objective law, individual rights, theory of law.

DOI: $10.17516 / 1997-1370-2015-8-8-1661-1666$.

Research area: law.

1. Discussion on law interpretation, held by Russian jurists in 80-90ies of the last century led to a remarkable, from our point of view, conclusion that none of the leading legal doctrines of our time - positivist, sociological, psychological, natural legal - alone currently not able to cover all of the essential, necessary facets of law. For these purposes, we need to use an integrative approach. V. Lazarev admits: "it is tempting to combine all the features meeting the interests of law enforcement into a single concept". At the same time, he believes that "following an integrative approach, we should not insist that a particular feature of law is inadmissible, or, on the contrary substantial, without which there is no right at all" 1 .

However, the circle of scholars who wish to implement the methodology of integrative approach so far is very narrow, which can be explained by two factors. First, the integrative approach, based on the free choice of the essential features of law, justified by different legal doctrines, is more reminiscent of the eclectics, rather than a creative scientific method. Since it proposes to look for essential features of law not in the immediate reality, but to join together different theories, different initial philosophical, theoretical and methodological foundations. Secondly, no representative of the leading legal doctrines is not ready to give up his doctrine of pure object to its appropriate understanding of the basics right dilute some additional features, justified by other legal theory. By changing the idea of the law, we need to change the contents of the corresponding theory, bring it into line with the newly understood law interpretation, which,

(C) Siberian Federal University. All rights reserved

* Corresponding author E-mail address: svm27@mail.ru 
in turn, would entail the loss of the theory in its integrity and originality.

2. Materialistic theory of law acts as a doctrine, which is capable of creative implementation of ideas of integrative approach on a purely scientific methodological basis, devoid of eclecticism and unilateralism, for which the law is a way of social relationship, ensuring stability and sustainability of society, existing in a social division of labor and dependence of each individual on other private owners and society in general. The law characterizes such a social relationship in which each individual, when interacting with others, is able to achieve something more, compared to what he had earlier, before entry into a legal relationship, without infringing on the rights, freedoms and property of others. The opposite, non-legal method is based on arbitrariness, abuse of one person over another.

3. The methodology of integrative law interpretation is a method of thinking from the abstract to the concrete, based on the following principles: 1) the recognition of the legal form of economic relations as an objective law, which has such universal properties as equality, freedom of will, interdependence, universality and equivalence; 2) The need for a systematic study of all the forms of the objective law in the transition from possibility into reality: positive law, individual rights, the specific law; 3) Historically the first form of objective law inherent in the exchange cultured under conditions of simple commodity production performs the function of the beginning of thinking from the abstract to the concrete, as it is the most simple form of objective law it most clearly and fully exhibits all essential features of law; 4) one should begin to study the modern law with the positive law, as it is the most abstract form of objective law, which can be confirmed by its claim to be the real universal law in the form of individual and particular (specific) law.

4. The basis of socially accepted law is the objective law, which is the legal form of the economic relations of production, distribution, exchange and consumption, designed to ensure that these relationships between subjects exist in accordance with their economic content. The unity of the legal form and economic substance was convincingly demonstrated by the historic first economic relation exchange, which became possible only after the two owners of private property were able to implement it on a purely legal basis of equality, free will, interdependence and equivalence. ${ }^{2}$ Note that the identification of these guidelines did not require complex scientific research. Individuals who experience a need for exchange of goods, without the help of the state, identified and implemented these principles; it has not lost its value today. Any currently existing economic relation of production, distribution, exchange and consumption has its inherent legal form, consistently the appropriate legal principles of universal equality, interdependence, free will, and the equivalence of universality and the very principles, which are recognized as fundamental principles of civil, commercial and other private laws.

Theory of law should give an answer to the question of what is the legal form, adequate to modern content of economic relations. Oriented to the disclosure of the functioning and development of the law, it is designed to give priority to the definition of an objective basis of law, the disclosure of the current state of the legal form of economic relations. However, it is well known that the Russian legal science professes the positivist doctrine, so this matter is automatically removed from the research on the grounds that it is beyond the subject of legal science and should be studied by economists. Russian and foreign jurisprudence currently does not have a clear understanding of 
the system of objective law and its legal norms and institutions. This knowledge will be obtained by the future research, successful development of which will allow jurists to stop looking at the empirical analysis of the text of dogmatic legal sources and to start looking at the realities of the immediate economic and legal practices.

The general principles of private law and their specifying norms act as a legal form of currently valid economic relations in their totality constitute a system of objective law. Thus, within the framework of the legal form of the materialist doctrine of economic relations, it has an objective character, as are economic relations; it acts independently of the will and desires of people.

5. Legal form as an objective law is not to be identified with the positive law. Firstly, the positive law, as established by the State and enshrined in the law or any other legal act, as well as any cognitive and volitional act, may deviate from the objective law, and exist in its converted form. Secondly, and most importantly, the transition of objective law from the possibility into reality is not limited by the positive law only, and also includes individual, specific and valid law to act independently and necessary manifestations of the objective law.

6. The individual law that is persistently ignored by the positivist doctrine, in fact, is a necessary form of the objective law, which it takes in the process of transition from a possibility into reality. At this stage the objective law takes the form of a unit on the level of consciousness of the individual so that later it can be successfully translated into concrete legal relationship and become a part of the moment of legal practice. Therefore, determining the degree of reality of the individual law, it is necessary not just to state the presence or absence of the universal, objective law, but to determine how fully and accurately the single unit reflects the universal and necessary content.
The process of formation of the individual law is of a complex nature and combines the three stages: the psychological, economic and legal. The formation of the law is being done through the understanding of the individual need and formation of the interest in a particular subject, the definition of the use value and exchange value of the subject and awareness of the individual economic viability. Not every subject of legal capacity is capable economically.

Choosing a legally significant action to acquire the object of necessity, the individual is not always guided by the existing norms of law. At this stage the individual appears to be truly free and can even consider a wrongful act as an embodiment of his (her) follow-up. The leading motif of the legally significant action chosen by the individual is his (her) material interest, the desire to get the maximum benefit. In cases where the possibility of its obtaining does not fit well with the law, the individual can ignore the law and seek new legal ways of implementing his (her) material or spiritual interests. It is in this way, still, individuals form new legal relations that best correspond to the current level of the economy.

Thus, it is not the positive law that acts as a force capable of making the individual enter into concrete private law relations, but first of all, it is a desire to meet the needs for food, shelter, clothing, and other material and spiritual wealth. The pattern for his (her) behavior is chosen as simply as possible in order to meet the relevant requirements, while ensuring full satisfaction of his (her) property and other interests, including getting the maximum benefit.

7. The positive law as a universal form of expression of the objective, like any act of comprehension of laws and universality, can correspond to objective rules and be in its real form, and may not reflect, may be the conversion of its form. Therefore, in cases where the 
individual law set out in the formal logical line with a converted form of positive law it is not valid.

The individual law corresponding to the converted form of the positive law is not able to acquire the attribute of reality, to become the real law. The form, following its core, cannot fix its flaws; it can only faithfully repeat and multiply them. Bona fide reproduction of the converted form of the positive law in the individual law of the individual does not approximate it to the reality of the objective law, but makes it more distant from it, creating the conditions for the realization of the subjective will of the legislator, cultivating relationships, hindering the action of the objective law and the development of protected values.

The legislation of the Soviet state, which had closed the NEP by its administrative measures, long before the economic prerequisites were created in the form of the measures of the state's ability to independently produce consumer goods in the amount necessary to meet the needs of the population, was the conversed form of the law. The legislation was ahead of the economic possibilities of the Soviet state, while the law cannot be higher than the economic and cultural level due to their development. The public authorities and law-abiding citizens who strictly abided by the laws of the state, used the conversed form of the law, acted lawfully, but not legally. Individuals who tried to circumvent the law to cultivate the right of a private owner for freely ownership and dispose of private property, were engaged in speculation, creating all sorts of illegal, clandestine enterprises acted in their own right, albeit illegally.

Thus, it is not possible to determine the validity of the individual law with the help of a formal logical comparison with the norms of the positive law. Only the objective law may be reliable criteria for this purpose. The completeness and accuracy of their reflection in the individual law can reliably show its validity or belonging to a converted form. Individual laws as a special stage of the transition of the objective law into reality are carefully designed to maintain the content of the latter in all its richness, to ensure its translation to the level of the individual and subjective, and in order to make sure how well the individual law fulfils its high destiny, it is necessary to compare it with the objective law. In addition, some of the standards of individual laws are formed by society, its members, bypassing the stage of the positive law, therefore in order to assess its validity we can use its direct base - the objective law.

The individual law (its individual rules or a set of rules) as well as the positive law can be recognized as valid, if it is first, consistent with its general principles: interdependence, equivalence, equality, free will and, secondly, specific standards, which is reflected in the fixed legal form of separate economic relations.

8. The specific law in the form of treaties and agreements acts as the third essential form that the objective law takes in the process of moving into reality. The actual specific law is common and coordinated will of the parties: it is set forth by the individual contract and corresponds general principles of the objective law. According to the materialist theory of law, specific requirements as well as the individual law can be recognized as valid, if they meet all the principles and specific rules of the objective law. If a specific right corresponds to the objective and contradicts the positive, then there is every reason to believe that the parties reached the agreement to find a new legal relationship, which most accurately reflects the current level of development of public relations and has every reason to run up to the level of the general rule of the positive law. The specific requirements laid down by the contract, do not comply with the general principles of law 
or actual norms of the positive law, other social norms are a transformed form, not capable of being translated into the objective law from the possibility into reality.

9. The real actors of a particular law are provided by the embodiment of the objective law in reality, when it becomes a point, a part of the political and legal practice. However, not every participant is obliged to seek legal proper performance of his (her) duties, in connection with which there is an urgent need for a state coercion, carried out by the public law.

The actual relationship provide indisputable evidence of the extent to subjective notions of objectiverules, cultivatedinthelegalconsciousness of society, the state and individuals correspond to the actual content of economic relations and what to do to ensure harmony between the legal form and content of the relationship. And this is seen as the most important socio-economic significance as a form of legal evidence, the final process of realization of the objective reality of law and ensuring the implementation of this function successfully or less successfully, and sometimes at all with negative results. The law, like any subjective activity, is based on objective results, can falter, leading to false results, and with this in mind, the process of transition of the objective validity of law is carried out in a multistage form, capable of neutralizing the subjectivism as a legislator, and the individual.

Given the above, the right is a relationship of individuals and other entities in which they come to meet their material and spiritual needs and which is based on the principles of equality, free will, interdependence and universal social equivalence. Strict adherence by all or most members of the community of the principles and rules of the objective law ensures the progressive development of economic, political, social and other spheres of modern society and society as a whole.
10. The multi-stage process of transition of the objective reality of law suggests that the interpretation of the laws contained in other legal theories represent only a special case of the above understanding of the law, the result of making it an absolute in this or that aspect of reality and real things. Therefore, the materialist theory does not deny the laws and other advances in the knowledge of theories that tend to rely on them, but puts them in the appropriate connection, depriving the famous one-sided, incomplete and inaccurate.

Thus, the materialistic doctrine takes the basic position of the theory of natural law of lying outside the law, and developing this position, showing that this acts as a legal form of economic relations.

The materialist theory of law itself with the positivist doctrine in the sense of positive law is an effective way to provide a single legal order in society, but it is not limited to this, and what is going on. Firstly, the materialist doctrine calls criteria (objective law), with which you can distinguish a real positive law from the legislative tyranny, and, secondly, depriving the positive law claims for the role of a regulator of social relations.

The materialist law interpretation fully supports the original position of the psychological theory about the ability of individual laws, the right to speak intuitive effective factor in the implementation of specific legal rights. However, this form of transition necessary objective law of possibility into reality in the materialistic theory of law specified and concretized and put in a proper relationship with positive and specific laws. The materialist doctrine does not deny the provisions of the sociological theory of law for legal relations as a valid form of law, but unlike it is considering as the legal outcome of the objective of transition right into a reality, prepared by his previous stages in the form of a 
positive, individual and specific rights. The legal relations themselves cannot act as a sole law.

Thus, the materialist theory of law consistently borrows progressive provisions of other legal theories and puts these provisions into a proper system of communication, using the integrative approach to implement its truly scientific basis, corresponding to the logic of the transition from the objective right opportunity into reality.

11. Logical forms of theoretical cognition of the objective law of transition of an opportunity into reality in particular relations in the materialistic theory of law serve as an ascent from the abstract to the concrete, which was first applied by G. Hegel in the "Philosophy of Law". However, this method is applied to the position of objective idealism, and did not contribute to the disclosure of the dialectics of objective and valid law. Dialectic laws were set and turned on its head. If positive law, in G. Hegel appears to be the highest, ultimate form of the idea of law, in fact, in real life, the formation of positive law serves only the first and the initial stage of realization of the objective law in reality. The greatest difficulty in society and the State beginning with the stage of incarnation of the positive law requiring coordination of the universal, the state will with the will of individuals and implementing the general will in all or most of the concrete relations.

Attempts by the Soviet jurists to move the ascent from the abstract to the concrete in the framework of the positivist doctrine also gave fruitful results. Therefore, the problem of disclosure of laws governing the development and functioning of law in materialist theory of the right appeared at the same time as the task of developing a logical form that could lead to the knowledge of the true nature of law and thereby deprive the relevance of a sarcastic remark of Kant, which he said two centuries ago that "lawyers are still looking for the law".

\footnotetext{
Lazarev V.V. Integrativnyi Podkhod k Pravomonimaniu. Teoriia Gosudarstva i Prava [The Integrative Approach to Law Interpretation. Theory of State and Law]. Moscow 2008. P. 269.

2 Marx K. Engels F. Works. Vol. 46 Part.1. P. 187-193.
}

\title{
Методология
}

\section{интегративного правопонимания}

\author{
В.М. Сырых \\ Российская академия правосудия \\ Россия, 119121, Москва, ул. Зубовская, 14
}

В статье анализируется материалистический тип правопонимания, интегрирующий достижения различных подходов к пониманию права. Обосновываются выводы об особом характере метода интегративного правопонимания, принципов его применения в процессе познания права, а также о стадийности реализаџии объективного права.

Ключевые слова: правопонимание, материалистическая теория права, позитивное право, объективное право, индивидуальное право, теория права.

Научная специальность: 12.00.00 - юридические науки. 